\title{
BASALTIC LAPILLI USED FOR CONSTRUCTION PURPOSES IN THE CANARY ISLANDS, SPAIN
}

\author{
Lomoschitz, A. ${ }^{a}$, Jiménez, J.R. ${ }^{a}$, Yepes, J. ${ }^{a}$, Pérez-Luzardo, J.M. ${ }^{b}$, Macías-Machín, A. ${ }^{c}$, Socorro, M. ${ }^{\text {, }}$ \\ Hernández, L.E. ${ }^{e}$, Rodríguez, J.A. ${ }^{f}$ Olalla, C. ${ }^{g}$ \\ a Department of Civil Engineering, Universidad de Las Palmas de Gran Canaria, 35017 - Las Palmas de GC, Spain \\ b School of Architecture, Universidad de Las Palmas de Gran Canaria, 35017 - Las Palmas de GC, Spain \\ c Department of Chemical Engineering, Universidad de Las Palmas de Gran Canaria, 35017 - Las Palmas de GC, Spain \\ d Department of Mechanical Engineering, Universidad de Las Palmas de Gran Canaria, 35017 - Las Palmas de GC, Spain \\ e Área de Laboratorios y Calidad de la Construcción, Viceconsejería de Infraestructura y Planificación, Gobierno de Canarias, C/ \\ Talavera s/n, Llano del Moro, 38291 Santa Cruz de Tenerife, Spain \\ $f$ Department of Edaphology and Geology, University of la Laguna, 38206 La Laguna, Spain \\ g Laboratory of Geotechnics, Centro de Estudios y Experimentación de Obras Públicas (CEDEX), C/Alfonso XII, 3, 28014 Madrid, \\ Spain
}

\begin{abstract}
Basaltic lapilli have been extensively used in the Canary Islands in the construction industry and their abundance encourages an understanding of their properties as aggregate. They are small pyroclastic fragments, dark colored, with 8.5 to 33 percent of interconnected voids. This high porosity is the cause of low unit weights; dry unit weight ranges between 8 and $12 \mathrm{kN} / \mathrm{m} 3(50.95-76.43 \mathrm{lb} / \mathrm{ft} 3)$ and moist unit weight usually varies between 11 and $16 \mathrm{kN} / \mathrm{m} 3$ (70.06-101.91 lb/ft3). From a geotechnical perspective, lapilli are essentially coarse granular material with friction angles of $34-37^{\circ}$, cohesion of $137-176 \mathrm{kN} / \mathrm{m} 2$ (2.86-3.68 lb/ft 2), and unconfined compressive strength, qu, equaling $0.39-0.54 \mathrm{MN} / \mathrm{m} 2(8.15-11.28 \mathrm{lb} / \mathrm{ft} 2)$. They are used as coarse aggregate in mass concrete and the compressive strength reaches $25.97 \mathrm{MPa}$ at 28 days, with a characteristic strength of $\mathrm{fck}=25 \mathrm{MPa}(3,625 \mathrm{lb} / \mathrm{in} .2)$. The lack of reactive silica eliminates alkali-silica reactivity problems with Portland cement. Concrete blocks with lapilli are normally used in the Canary Islands. The 250d type provides the best characteristics and even serves for structural bearing walls. It reaches a high block strength index ( $\mathrm{Bk} \geq 6 \mathrm{~N} / \mathrm{mm} 2$ ), and provides effective sound and thermal insulation. This material can also be used as a granular material for highways, although the results from compaction tests (Proctor and CBR) vary widely. This extensive Canarian experience with basaltic lapilli could serve as a useful guide for other volcanic areas of the world.
\end{abstract}

